\title{
Myriophyllum spicatum'un Süperoksit Dismutaz Enzim Aktivitesi, Lipid Peroksidasyonu ve Hidrojen Peroksit Seviyesi Üzerine Nano ve Mikro Bor Partiküllerinin Etkisi
}

\author{
Yeșim DAĞLIOĞLU ${ }^{1 *}$, Sevda TÜRKİ̧ ${ }^{2}$ \\ ${ }^{1}$ Ordu Üniversitesi, Fen Edebiyat Fakültesi Moleküler Biyoloji ve Genetik Bölümü, Ordu \\ ${ }^{2}$ Ordu Üniversitesi, Eğitim Fakültesi, Illkögretim Bölümü, Ordu
}

\begin{abstract}
Özet
Bitkiler, karşılaştıkları stres faktörleri karşısında antioksidan enzim savunması ile karşılık verir. Bu enzimlerden birisi süperoksit dismutaz (SOD) olup süperoksit radikalini yok etmeden sorumludur. Lipid peroksidasyonu, reaktif oksijen türlerinin (ROT)'nin membranın lipid tabakasının peroksidasyonu sonucu olarak hücre membran sistemlerinde metabolik değişikliklere yol açan oksidatif hasarlardır. Bu çalışmada, Myriophyllum Spicatum 72 saat boyunca nano ve mikro B partiküllerinin 50, 100 ve $200 \mathrm{ml}^{-1}$ konsantrasyonlarında maruz bırakılmıştır. Yapılan istatistik çalışmasında, kontrol grubuna göre nano ve mikro B partiküllerinin MDA, SOD, $\mathrm{H}_{2} \mathrm{O}_{2}$ değerleri açısından tüm maruz kalan gruplarda önemli farklılıklar olduğu tespit edilmiştir $(p<0.01)$. Genel olarak, $\mathrm{H}_{2} \mathrm{O}_{2}$, MDA ve SOD enzim aktivitesi nano borda mikro bordan daha yüksek ölçülmüştür. Ayrıca, Myriophyllum spicatum membranları genel olarak nano ve mikro B partiküllerinden zarar görmemiştir sadece, nano B' un 50 mg1 konsantrasyonunda düşük seviyede membran hasarı gözlenmiştir. Bu sonuçlara göre nano bor partikül toksisitesinin mikro bordan daha fazla olduğunu söyleyebiliriz. Ayrıca, nano borun düşük konsantrasyonlarda daha toksik olduğu söylenebilir. Bu sonuçlar nanopartiküllerin yoğun konsantrasyonlarda agregasyon oluşturması ve bundan dolayı hücre içerisine alımının daha az olması şekilinde tahmin edilir.
\end{abstract}

Anahtar kelimeler: Bor, Nanopartikül, Myriophyllum spicatum, SOD, MDA, $\mathrm{H}_{2} \mathrm{O}_{2}$.

\section{Effect of Nano and Micro-Particle Boron on Hydrogen Peroxide and Lipid Peroxidation Enzyme Actıvity Superoxıde Dismutase of Myriophyllum Spicatum}

\begin{abstract}
Plants respond with antioxidant enzyme defense against the stress factors they meet. One of these enzymes is superoxide dismutase (SOD) and is responsible for eliminating the superoxide radical. Lipid peroxidation is the oxidative damage caused by reactive oxygen species (ROS) metabolic changes in cell membrane systems resulting in peroxidation of the lipid layer of the membrane. In this study, Myriophyllum spicatum were exposed to nano and micro boron particles 72 hours 50, 100 and $200 \mathrm{ml}^{-1}$ concentration. According to the statistical study, nano and micro boron particles were significantly different in MDA, SOD, $\mathrm{H}_{2} \mathrm{O}_{2}$ values in all exposed groups according to control group $(p<0.01)$. In general, $\mathrm{H}_{2} \mathrm{O}_{2}$, MDA and SOD enzyme activity is measured higher in nano boron than in micro boron. Myriophyllum spicatum membranes were generally not damaged by nano and micro boron particles, only low level membrane damage was observed at a concentration of $50 \mathrm{mg}^{-1}$ of nano boron. According to these results, we can say that nano boron particle toxicity is more than micro boron. Moreover, it can be said that nano boron is more toxic at low concentrations. These results are estimated to be that the nanoparticles aggregate at dense concentrations and therefore less intracellular uptake.
\end{abstract}

Keywords: Boron, Nanoparticles, Myriophyllum spicatum, SOD, MDA, $\mathrm{H}_{2} \mathrm{O}_{2}$.

\footnotetext{
*Sorumlu yazar: yozkan52@gmail.com

Geliş Tarihi: 13/01/2017 Kabul Tarihi: 03/07/2017
} 


\section{Giriş}

Nanopartikül (NP) $(<100 \mathrm{~nm})$ toksisitesi, ekotoksikolojik araştırmalar için nisbeten oldukça yeni bir bilim dalı olup 'nanotoksikoloji' olarak literatüre geçmiştir. Nanotoksikoloji, NP'lerden kaynaklanan sağlığa zararlı etkilerin açıklandığı toksikolojinin yeni bir alt dalı olarak ifade edilmektedir [1]. Nanoteknoloji endüstrisi, maddelerin nano ölçekte alışılmamış özelliklerinin keşfedilmesiyle hızlı bir gelişim göstermiş ve bu özellikleri ile potansiyel toksisiteleri ve ekotoksikolojileri hakkında endişelere sebep olmuştur. NP'lerin kuantum davranışlarının değişmesi ve reaktivitelerinin artması bunları pek çok uygulamada kullanılabilir hale getirmiştir. NP'lerin üretimi ve uygulamalarının hızlı artışı, insan sağlığı, çevre ve canlı organizmalar üzerinde beklenmedik etkiler meydana getirebilme olasılı̆̆ını artırmıştır [2]. NP'ler, küçük (nano-ölçek) boyutu, spesifik yüzey alanı ve yüzey enerjisinden dolayı aynı kimyasal bileşime sahip moleküller ve yığın malzemeler ile kıyaslandığında oldukça farklı fiziko-kimyasal özelliklere sahiptir [2], [3]. Ayrıca, NP'ler zeta potansiyeli, hidrodinamik çapı, partikül boyut dağılımı, parçacık boyutu, kimyasal kompozisyonu ile karakterize edilir [2]. Bor (B) ile üretilen malzemelerin, koruyucu kaplamalar [4], yüksek yoğunluklu yakıtlar [5] ve kanser tedavisi [6] gibi yarı iletken alanlarında çok çeşitli uygulamaları vardır [7]. NP'lerin bu yaygın kullanımlarından dolayı önemli miktarları, akuatik, karasal ve atmosferik çevrelerde bulunmaktadır [8]. NP'lerin serbest kalmasıyla ilişkili risklerinin, yaşayan organizmalar üzerinde biyolojik etkilerini araştıran çalışmalara ihtiyaç vardır [9], [10], [42]. Bununla birlikte, çevrede degradasyon ve biyoyararlanımını içeren NP'lerin akibeti hakkında daha fazla bilgi gereklidir [3]. NP'lerin bitkiler tarafindan alımı ve birikimi araştırmacılar tarafından önemi giderek artan bir konu olup son zamanlarda bu konuyla ilgili bazı bilimsel çalışmalar yayınlanmıştır. NP'lerin bitkilerde yapraklara kadar ulaşması için, öncelikle vasküler dokulara (ksilem) girmesi gerekir. Bunun için NP'ler köklerde epidermal katmanların plazma membranlarını ve hücre duvarlarını geçmek zorundadır. Köklerin hücre duvarları polisakarit fiber matris gözenekli ağ yapısında olmasından dolayı su molekülleri ve diğer çözünenlerin öncelikle bu ağı geçmesi gerekir. Bitki duvarlarının gözenek boyutları tipik olarak 3-8 nm aralığında olup test edilen pek çok nanopartikülden daha küçüktür [11]. Navarro vd., 2008 hücre duvarlarının tipik olarak doğal elekler gibi yaklaşık 5 ila $20 \mathrm{~nm}$ kalınlığında olduğu hipotezini kurmuştur. En büyük gözeneklerden daha küçük bir boyuta sahip NP ve NP agregatlarının plazma zarına ulaşması ve geçmesi beklenirken, daha büyüklerini bitki hücrelerinden geçememesi beklenir. Ayrıca, NP'lerin, hücre duvarlarını etkilemesi sayesinde, büyük NP'lerinde hücre duvarından geçmesine izin veren büyük ve yeni gözeneklerin oluşumuna neden olabilir [12], [13]. Bununla birlikte, farklı bitki türlerinde farklı boyut ve bileşimli NP’lerin hücreler tarafından içselleştirmesi gözlenmiştir [14], [15].

Metal ve metal oksit, karbon nanotüp $(\mathrm{CN})$, fullerenler, gibi çeşitli kimyasal kompozisyonlu nanopartiküllerin oksidatif strese neden olduğu daha önceki çalışmalarda gösterilmiştir [16], [17], [18]. Abiyotik stres şartları altında bitkilerde reaktif oksijen türleri (ROT) olarak adlandırılan oldukça toksik ve reaktif moleküller oluşmaktadır. Bu moleküller protein, lipid, karbohidrat ve DNA'nın yapısını bozarak oksidatif stresin oluşmasına neden olmaktadır. Bitkiler, bu hasarları önlemesi için antioksidant savunma sistemlerine sahiptir. $\mathrm{Bu}$ antioksidant sistemler enzimatik (süperoksit dismutaz, katalaz, askorbat peroksidaz, glutatyon redüktaz vb.) ve enzimatik olmayan (fenolik bileşikler, alkoloid, askorbik asit, glutatyon vb.) şekilde ikiye ayrılır [19]. NP kaynaklı ROT oluşumunda kilit rol oynayan faktörler NP'lerin reaktif yüzeyi üzerinde bulunan pro-oksidan işlevsel gruplar ve metal bazlı NP'lerin geçişinden dolayı nanopartikül yüzeylerinde oluşan aktif redoks döngüsü ve partikül hücre etkileşimleridir [20], [21]. Hem in vivo hemde in vitro da çeşitli NP'lerin ROT oluşturduğu gösterilmiştir. Hücrede ROT üretimi, C60, SWCNT, kuantum noktaları ve ultra ince partiküller gibi çeşitli NP'ler tarafından oluştuğu gözlenmiştir [22]. Endüstriyel atıkların çoğunun ve şehirsel atık su deşarjlarının nehirlere, göllere ve kıyısal sulara karıştı̆̆ iyi bilinen bir gerçektir. Bu nedenle, nanoölçekli endüstriyel ürünler ve yan ürünlerin sucul ortamlara karışması kaçınılmazdır [23].

Sucul bitkiler ve algler, kirlenen sulardan metal ve diğer toksik elementleri biriktirmesi ile bilinmektedir [24], [25], [26], [27]. Başaklı su civanperçemi (Myriophyllum spicatum L,) farklı su sistemlerine hâkim hızla bitki sağlayan güçlü büyüme ve yayılma stratejileri gösteren sualtı bir türdür [28], [29]. Göllerde, 1rmaklarda ve sulama sistemlerinde gelişir. Tatlı sulardan, tuzlu sulara kadar değişik nitelikli sularda, 5 $\mathrm{m}$ derinliğe kadar yaşayabilir. Serin sularda da kışlayabilir. Tohumla ya da bitki parçaları aracılığıyla ürerler. Türkiye'de çeşitli su kaynakları ile sulama ve boşaltma kanallarında yaygın olup sorun yaratan bir türdür [30]. Su içinde çok dallı bir yapıya sahip, $90 \mathrm{~cm}$ ile $3 \mathrm{~m}$ aralığındaki derinliklerde 
görülebilmektedirler [31]. Bu doğal bitki örtüsü yerini değiştirebilir. Civanperçeminin hâkim olduğu göller genellikle düşük fitoplankton yoğunluklarına sahiptir. Canopy (örtü) yapımı, açık sulardan besin kaldırma, otomatik parçalanmayla yayılan yoğun bitki örtüsü ve düşük ışık ve $\mathrm{CO}_{2}$ karşılama noktaları gibi çeşitli morfolojik ve fizyolojik stratejileri olan civanperçeminin son derece rekabetçi gücünden dolayı bu çalışmada tercih edilmiştir [28], [32], [33], [34], [35].

Bazı nanopartiküllerin algler, tatlı su omurgasızları ve balıklarında dahil olduğu sucul organizmalar üzerinde yoğun çalışmaları olmasına rağmen akuatik bitkiler üzerinde bor nanopartiküllerinin etkileri hakkında çalışmalar henüz yapılmamıştır. Bu çalışmada, yüksek su bitkileri için model organizma olan ve laboratuvar çalışmalarında yaygın kullanılan test bitkisi Myriophyllum spicatum kullanılmıştır. Bu çalışmanın temel amacı büyüme koşulları altında nano ve mikro B partiküllerine 72 saat maruz bırakılan Myriophyllum spicatum'un malondialdehit (MDA), Süperoksit dismütaz (SOD) ve Hidrojen peroksit $\left(\mathrm{H}_{2} \mathrm{O}_{2}\right)$ seviyelerinin karşılaştırılmalı değerlendirilerek akut toksik etkileri araştırılmıştır.

\section{Materyal ve Metot}

\subsection{Bitki materyali ve bor partiküllerin uygulaması}

Myriophyllum spicatum (Civanperçemi) Muğla-Köyceğiz Kargıcak Dere'sinden toplanarak temin edilmiştir. Denemeye başlamadan üç gün önce laboratuvar koşullarına uyum sağlaması için laboratuvarda bekletilmiştir. Daha sonra, bitki örneklerinin mineral beslenme ortamlarında deneme süresince uygulanmak üzere modifiye edilmiş Hoagland besin çözeltisi hazırlanmıştır [36]. Myriophyllum spicatum'ne stres faktörü olarak mikro ve nano B partikülleri $500 \mathrm{ml}$ polietilen şişelerde uygulanmıştır. Bu şişelerde karışımı sağlamak için akvaryum hava motoru kullanılmıştır.

\subsection{Lipid peroksidasyonu (MDA)}

Tiobarbiturik asit (TBA), lipit peroksidasyonunun son ürünü olan malondialdehiti (MDA) belirlemek için kullanıldı. Kontrol grubu ve maruz kalan gruplarda $200 \mathrm{mg}$ bitki örnekleri $10 \mathrm{ml} \% 0.1$ trikloro asetik asit (TCA) çözeltisi içinde homojenize edildi. Elde edilen homojenat $15000 \mathrm{~g}$ de $10 \mathrm{dk}$ santrifüj edildi. $1 \mathrm{ml}$ süpernatant ve $4 \mathrm{ml}$ TBA reaktifi (\%5'lik TBA, $4 \mathrm{ml} \% 20$ TCA $1 \mathrm{ml} \% 2$ etanol de butile hidroksitolüen) içeren reaksiyon karışımı $90{ }^{\circ} \mathrm{C}$ ' sıcak su banyosu içinde 20 dakika boyunca 1sitıldı ve hemen buz banyosunda soğutuldu. Daha sonra, $15000 \mathrm{~g}$ de 10 dakika santrifüjlenen MDA-TBA karışımı absorbansı $532 \mathrm{~nm}$ dalga boyunda belirlendi. MDA-TBA karışımının bu konsantrasyonu absorbans katsayısindan hesapland1 [38].

$\operatorname{MDA}\left(\mathrm{nmol} \mathrm{ml} l^{-1}\right)=[(\mathrm{A} 532-\mathrm{A} 600) / 155000] 10^{6}$

\subsection{Hidrojen peroksit $\left(\mathrm{H}_{2} \mathrm{O}_{2}\right)$}

Hidrojen peroksit seviyesi küçük bir değişiklikle Mukherjee ve Choudhuri 1983 tarafından tanımlanan metoda göre belirlenmiştir [39]. Öncelikle titanyum çözeltisi hazırlanmıştır, bunun için $1 \mathrm{~g} \mathrm{TiO}_{2}$ ve 10 $\mathrm{g} \mathrm{K}_{2} \mathrm{SO}_{4} 150 \mathrm{ml}$ konsantre $\mathrm{H}_{2} \mathrm{SO}_{4}$ ile 1sitıcı tablada 2 saat kaynatıldı soğutulduktan sonra 1.5 litreye tamamland1. 0.5 gram tartılan bitki $10 \mathrm{ml}$ soğuk aseton ile homojenize edilip homojenat Whatman filtre kâğıdı ile süzüldü. Ekstrakt üzerine $4 \mathrm{ml} \mathrm{TiO}_{2}$ çözeltisi ve $5 \mathrm{ml}$ konsantre $\mathrm{NH}_{3}$ çözeltisi konuldu. 10000 $\mathrm{g}$ de 5 dakika santrifüj edilip, berrak kısım döküldü ve çökelti $10 \mathrm{ml} 1 \mathrm{M} \mathrm{H}_{2} \mathrm{SO}_{4}$ ile çözüldü. Tekrar 10 000 g' de 5 dakika santrifüjlenerek çözünmeyen kısım atıldı ve $415 \mathrm{~nm} \mathrm{de} \mathrm{H}_{2} \mathrm{O}_{2}$ belirlendi. [39], [40].

\subsection{Süperoksit dismutaz (SOD) enzim aktivitesi}

Beauchamp ve Fridovich 1971 tarafindan tarif edildiği gibi SOD aktivitesi ölçülmüştür [41]. Bir birim, nitro mavi tetrazolyum (NBT) azalması ile \% 50'lik bir azalmaya neden olan enzim miktarı olarak tanımlanmıştır. Kısaca, NBT'nin 560 nm' de inhibasyonu ile belirlenmiştir. 


\section{6. İstatistiksel analizler}

Myriophyllum spicatum L. 50, 100 ve $200 \mathrm{ml}^{-1}$ konsantrasyonlarında nano ve mikro B miktarları için elde edilen değerlerin istatistiki açıdan farklılıkları SPSS 15 programında ANOVA, Tukey testleri ve Pearson korelasyonu yapılarak tespit edildi.

\section{Bulgular}

Myriophyllum spicatum, L. nano ve mikro B partiküllerine 50, 100 ve $200 \mathrm{ml}^{-1}$ konsantrasyonlarında 72 saat maruz bırakıldıkta sonra SOD enzim aktivitesi, MDA ve $\mathrm{H}_{2} \mathrm{O}_{2}$ seviyesi spektrofotometre ile ölçüldü. Bor partiküllerinin etkilerine ait gerçekleştirilen ANOVA testi sonuçlarına göre $p<0.01$ düzeyinde önemli farkl111klar tespit edildi ve farkl111kların sebebi ise Tukey testi ile belirlendi.

Tablo 1'de M. Spicatum'un 72 saat nano B partiküllerine maruz kalmada MDA, SOD, $\mathrm{H}_{2} \mathrm{O}_{2}$ değerleri açısından tüm maruz kalan gruplarda önemli farkl11ıklar tespit edildi $(p<0.01)$ (Şekil 1). Farklı konsantrasyon uygulamalarındaki önemli farklılığın sebebi Tukey testine göre tüm dozlar sebep olmuş olup, $50 \mathrm{mg}^{-1}$ konsantrasyonda en fazla farkl1lık belirlenmiştir. MDA ve $\mathrm{H}_{2} \mathrm{O}_{2}$ de $50 \mathrm{mg}^{-1} \mathrm{SOD}$ da ise $100 \mathrm{mg}^{-1}$ de en fazla farklılık tespit edilmiştir.

Tablo 1. Farklı enzim aktivitelerinde nano B varyans analiz sonuçları.

\begin{tabular}{|c|c|c|c|c|c|}
\hline \multicolumn{6}{|c|}{ ANOVA } \\
\hline & Enzim & & & & Tukey \\
\hline & aktivitesi (unit.mg-1) & Serbestlik & & & Testi \\
\hline & & faktörü & F oran1 & P değeri & \\
\hline \multirow{3}{*}{ MDA } & Gruplar arasında & 2 & 301.00 & 0.00 & $0.0243^{\mathrm{a}}$ \\
\hline & Gruplar içinde & 6 & & & \\
\hline & Toplam & 8 & & & $(50 \mathrm{mg} / \mathrm{lt})$ \\
\hline \multirow{3}{*}{ SOD } & Gruplar arasında & 2 & 119.431 .00 & $\mathbf{0 . 0 0}$ & $0.1610^{\mathrm{a}}$ \\
\hline & Gruplar içinde & 6 & & & $(100 \mathrm{mg} / \mathrm{lt})$ \\
\hline & Toplam & 8 & & & \\
\hline \multirow{3}{*}{$\mathrm{H}_{2} \mathrm{O}_{2}$} & Gruplar arasında & 2 & 89.053 .00 & 0.00 & $0.1543^{\mathrm{a}}$ \\
\hline & Gruplar içinde & 6 & & & $(50 \mathrm{mg} / \mathrm{lt})$ \\
\hline & Toplam & 8 & & & \\
\hline
\end{tabular}

Myriophyllum spicatum 72 saat nano B uygulamasında kontrol grubu ile karşılaştırıldığında, MDA seviyesi bakımından 100 ve $200 \mathrm{mg}^{-1}$ maruz kalan gruplarda düşük olmasına rağmen $50 \mathrm{mg}^{-1}$ (en düşük konsantrasyon) da yüksektir. Maruz kalınan konsantrasyon arttıkça kontrol grubu seviyelerinden daha düşük ölçülerde MDA seviyesi kaydedilmiştir. SOD enzim aktivitesinde maruz kalan grupların konsantrasyon miktarı arttıkça kontrol grubundan çok daha fazla enzim aktivitesi ölçülmüştür. $\mathrm{H}_{2} \mathrm{O}_{2}$ enzim aktivitesi tüm maruz kalan gruplarda kontrol grubundan daha yüksektir. Fakat 100 ve $200 \mathrm{mg}^{-1}$ maruz kalan gruplarda $50 \mathrm{mg}^{-1}$ (en düşük konsantrasyon)'dan daha az ölçülmüştür (Şekil 1). 


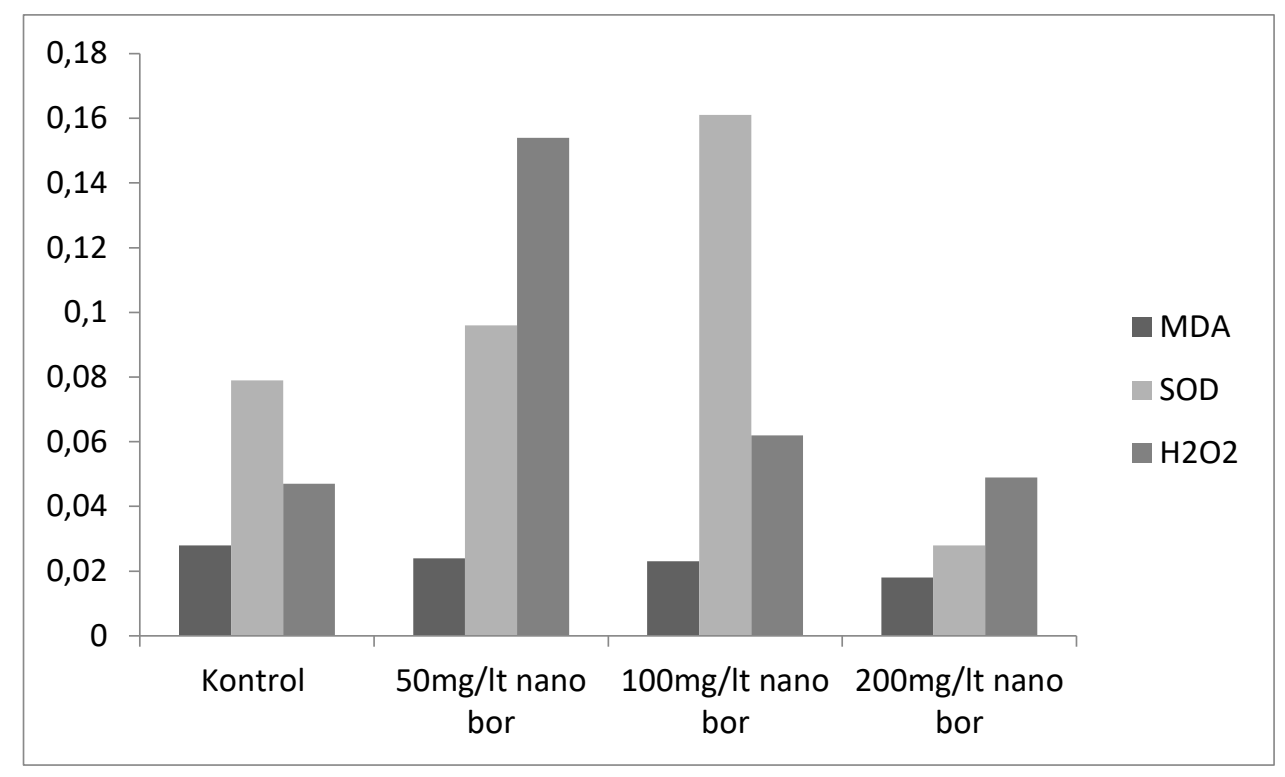

Şekil 1.Enzim aktivitelerinde farklı nano B miktarlarının karşılaştırılması

Tablo 2'de M. Spicatum'un 72 saatlik zamanda MDA, SOD, $\mathrm{H}_{2} \mathrm{O}_{2}$ değerleri açısından mikro B partiküllerinde tüm dozlar arası önemli farkl1lıklar tespit edilmiştir $(p<0.01)$. Farklı doz uygulamalarındaki önemli farklılığın sebebi Tukey testine göre MDA için $200 \mathrm{mg}^{-1}$, SOD için $100 \mathrm{mg}^{-}$ ${ }^{1}$ ve $\mathrm{H}_{2} \mathrm{O}_{2}$ için $50 \mathrm{mg}^{-1}$ de en fazla farklılık belirlenmiştir.

Tablo 2. Farklı enzim aktivitelerinde mikro B'un varyans analiz sonuçları

\begin{tabular}{|c|c|c|c|c|c|}
\hline \multicolumn{6}{|c|}{ ANOVA } \\
\hline & $\begin{array}{c}\text { Katalaz enzim } \\
\text { aktivitesi (unit.mg-1) }\end{array}$ & $\begin{array}{l}\text { Serbestlik } \\
\text { faktörü }\end{array}$ & F oran1 & $\begin{array}{c}\mathrm{P} \\
\text { değeri }\end{array}$ & $\begin{array}{l}\text { Tukey } \\
\text { Testi }\end{array}$ \\
\hline \multirow{3}{*}{ MDA } & Gruplar arasında & 2 & 628.00 & 0.000 & $0.0260^{\mathrm{a}}$ \\
\hline & Gruplar içinde & 6 & & & \\
\hline & Toplam & 8 & & & $(200 \mathrm{mg} / \mathrm{lt})$ \\
\hline \multirow{3}{*}{ SOD } & Gruplar arasında & 2 & 35356.00 & 0.000 & $0.1650^{\mathrm{a}}$ \\
\hline & Gruplar içinde & 6 & & & $(100 \mathrm{mg} / \mathrm{lt})$ \\
\hline & Toplam & 8 & & & \\
\hline \multirow{3}{*}{$\mathrm{H}_{2} \mathrm{O}_{2}$} & Gruplar arasında & 2 & 22411.00 & 0.000 & $0.0870^{\mathrm{a}}$ \\
\hline & Gruplar içinde & 6 & & & $(50 \mathrm{mg} / \mathrm{lt})$ \\
\hline & Toplam & 8 & & & \\
\hline
\end{tabular}

Myriophyllum spicatum 72 saat mikro B uygulamasında kontrol grubu ile karşılaştırıldığında, MDA seviyesi bakımından maruz kalan gruplarda kontrole göre daha az ölçülmüştür. SOD da ise tüm maruz kalan gruplarda çok daha yüksek ölçülmüş, özellikle $100 \mathrm{mg}^{-1}$ konsantrasyonda kontrol grubunun iki katından fazla ölçülmüştür. $\mathrm{H}_{2} \mathrm{O}_{2}$ de ise en yüksek konsantrasyonlarda $\left(100\right.$ ve $\left.200 \mathrm{mg}^{-1}\right)$ düşük ölçülmüş, $50 \mathrm{mg}^{-1}$ (en düşük) konsantrasyonda kontrol grubunun iki katından daha fazla ölçülmüştür (Şekil 2). 


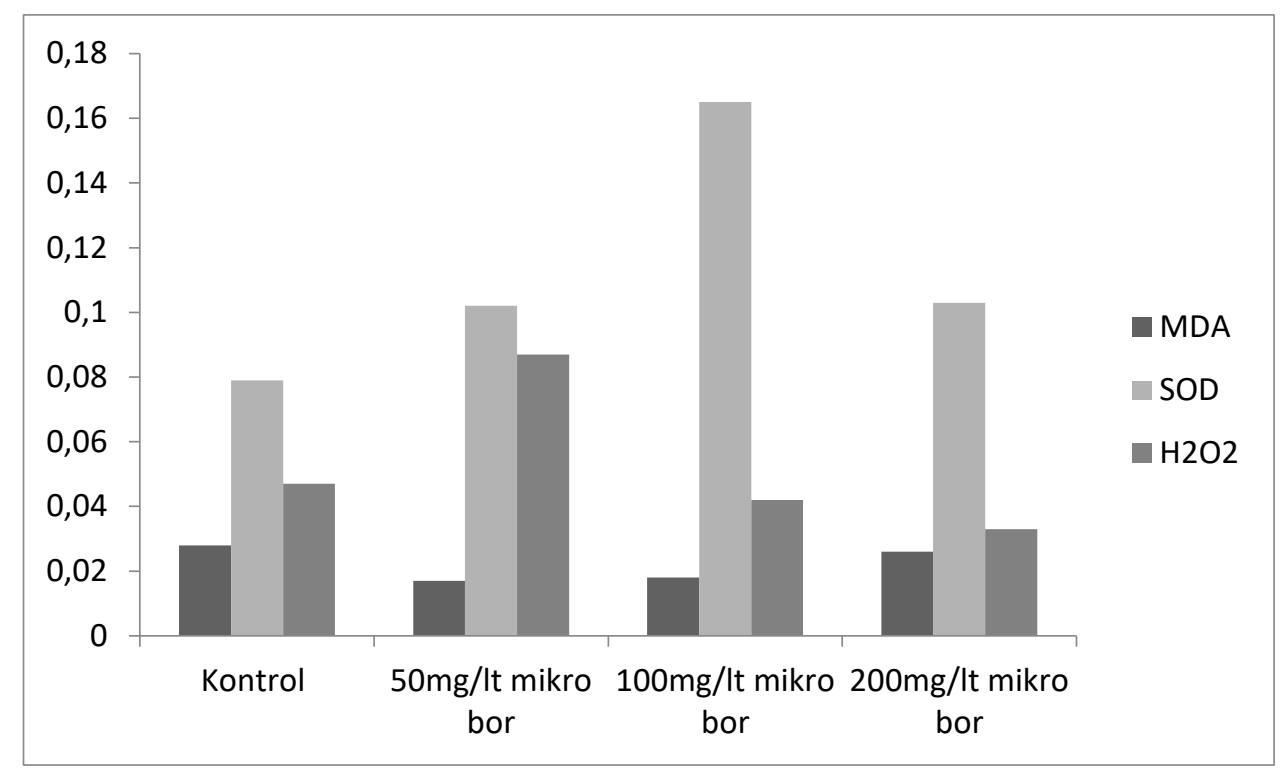

Şekil 2.Enzim aktivitelerinde farklı mikro B miktarlarının karşılaştırılması

Gerçekleştirilen Pearson korelasyon sonuçlarına göre ise $p<0.05$ önemlilik düzeyinde korelasyonlar tespit edilmiştir (Tablo 3 ve 4). Myriophyllum spicatum 72 saat nano ve mikro B uygulamalarında pearson korelasyon sonuçlarına göre; nano B uygulamalarında MDA ile SOD, MDA ile $\mathrm{H}_{2} \mathrm{O}_{2}$ ve SOD ile $\mathrm{H}_{2} \mathrm{O}_{2}$ arasında $50 \mathrm{mg}^{-1}$ konsantrasyonda pozitif korelasyonlar tespit edilmiştir (Tablo 3). Mikro B uygulamalarında ise SOD ile MDA, $\mathrm{H}_{2} \mathrm{O}_{2}$ ile MDA arasında $50 \mathrm{mg}^{-1} \mathrm{de}$ negatif korelasyonlar tespit edilmiştir (Tablo 3).

Tablo 3. Farklı enzim aktivitelerinde nano ve mikro B değerlerinin korelasyon sonuçları

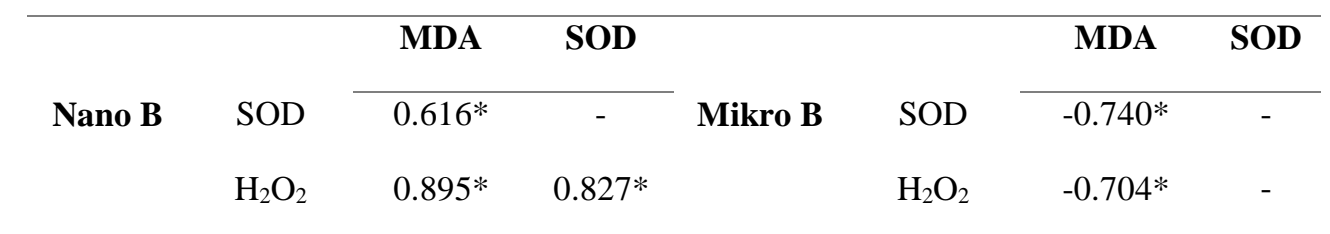

(SOD, MDA, $\mathrm{H}_{2} \mathrm{O}_{2}, * P<0.05$ düzeyinde önemlidir).

\section{Sonuç}

Myriophyllum spicatum membranlarının nano ve mikro B partikülü stres uygulamasında zarar görmemiştir. Çünkü maruz kalan grupların lipid peroksidasyon miktarı, kontrol grubunda ölçülen MDA miktarı ile karşılaştırıldığında MDA seviyesinde azalma olmuştur. Sadece nano B'un $50 \mathrm{mg}^{-1}$ konsantrasyonda düşük seviyede membran hasarı gözlenmiştir. Ayrıca, nano B'un SOD enzim aktivitesi ve $\mathrm{H}_{2} \mathrm{O}_{2}$ seviyesi tüm maruz kalan gruplarda kontrol grubuna kıyasla yüksek ölçülmüştür. Fakat, SOD için $100 \mathrm{mg}^{-1}, \mathrm{H}_{2} \mathrm{O}_{2}$ için $50 \mathrm{mg}^{-1}$ konsantrosyanları kontrol grubu ve diğer konsantrasyon gruplarından çok daha yüksek seviyede ölçülmüştür. MDA seviyesi SOD ve $\mathrm{H}_{2} \mathrm{O}_{2}$ den farklı olarak en yüksek konsantrasyonlarda 100 ve $200 \mathrm{mg}^{-1}$ da kontrol grubundan daha az ölçülmüştür. En düşük konsantrasyon olan $50 \mathrm{mg}^{-1}$ da kontrol ve diğer maruz kalan gruplardan daha yüksek ölçülmüştür. Mikro B partiküllerinin MDA aktivitesi, maruz kalan tüm konsantrasyon grupları kontrol grubundan daha az ölçülmüştür. SOD da ise tüm konsantrasyonlarda enzim aktivitesi çok daha fazla ölçülmüş olup 50, 100 ve $200 \mathrm{mg}^{-1}$ konsantrasyonlarda sırasıyla $\% 129, \% 208$ ve $\% 130$ oranlarındadır. $\mathrm{H}_{2} \mathrm{O}_{2}$ de en düşük konsantrasyon hariç diğer konsantrasyonlarda enzim aktivitesi düşük ölçülmüştür (Tablo 4). 
Tablo 4. Nano ve mikro B partiküllerinin MDA, SOD ve $\mathrm{H}_{2} \mathrm{O}_{2}$ değerleri

\begin{tabular}{ccccccc}
\hline \multirow{2}{*}{$\begin{array}{c}\text { Konsantrasyonlar } \\
\left(\mathrm{mg}^{-1}\right)\end{array}$} & \multicolumn{2}{c}{ MDA } & \multicolumn{2}{c}{ SOD } & \multicolumn{2}{c}{$\mathrm{H}_{2} \mathrm{O}_{2}$} \\
\cline { 2 - 7 } & nano bor & mikro bor & nano bor & mikro bor & nano bor & mikro bor \\
\hline 0 & 28 & 28 & 79 & 79 & 47 & 47 \\
50 & 29 & 17 & 96 & 102 & 154 & 87 \\
100 & 18 & 23 & 161 & 165 & 62 & 42 \\
200 & 26 & 18 & 28 & 103 & 49 & 33 \\
\hline
\end{tabular}

Değerler bin ile çarpılmıştır (x1000)

Nano ve mikro B partiküllerinin MDA, ve $\mathrm{H}_{2} \mathrm{O}_{2}$ seviyeleri ile $\mathrm{SOD}$ enzim aktiviteleri birbiriyle ve maruz kalınan konsantrasyon gruplarına göre karşılaştırdığımızda, MDA seviyesi, nano B'un $50 \mathrm{mg}^{-1}$ konsantrasyonunda en yüksek miktarda tespit edilmiş̧ir ve buda nano B'un hücre hasarının mikro B'dan fazla olduğunu gösterir. Ayrıca genel olarak, MDA seviyesi üzerine B partikülleri etkili değildir. SOD enzim aktivitesi üzerine mikro B daha etkili olup $200 \mathrm{mg}^{-1}$ nano B konsantrasyonunda SOD aktivitesi oldukça fazla düşmüştür. $\mathrm{H}_{2} \mathrm{O}_{2}$ seviyesinde ise nano $\mathrm{B}$ mikro B'a göre daha toksiktir. Mikro B'un 50 $\mathrm{mg}^{-1}$ konsantrasyonu hariç diğer konsantrasyonları kontrol grubundan daha düşük ölçülmüştür. $\mathrm{Bu}$ verilere baktığımızda genel olarak nano B partiküllerinin toksisitesinin mikro B dan daha fazla olduğunu söyleyebiliriz. Ayrıca, yine genel olarak nano B'un düşük konsantrasyonlarda daha toksik olduğu söylenebilir. Bunu sebebinin nanopartiküllerin yoğun konsantrasyonlarda agregasyon (kümeleşme) oluşturması ve bundan dolayı hücre içerisine alımının daha az olması şekilinde tahmin edilir.

\section{Kaynaklar}

1. Handy R.D., Owen R., Valsami-Jones E. 2008. The Ecotoxicology of Nanoparticles and Nanomaterials: Current Status, Knowledge Gaps, Challenges, and Future Needs, Ecotoxicology, 17: 315-325.

2. Donaldson K., Stone V., Tran C.L., Kreyling W., Borm P.J.A. 2004. Nanotoxicology, Occup. Environ. Med., 61: 727-728.

3. Juhel G., Batisse E., Hugues Q., Daly D., Van Pelt N.A.M.F., O’Halloran J., Jansen A.K.M., 2011. Alumina Nanoparticles Enhance Growth of Lemna Minor, Aquatic Toxicology, 105: 328-336.

4. Bekish Y.N., Poznyak S.K., Tsybulskaya L.S., Gaevskaya T.V. 2010. Electrodeposited Ni-B Alloy Coatings: Structure, Corrosion Resistance and Mechanical Properties, Electrochim. Acta, 55: 2223 2231.

5. Van Devener B., Perez J.P.L., Jankovich, J., Anderson, S.L. 2009. Oxide-free, Catalyst-coated, Fuel-soluble, Air-stable Boron Nanopowder as Combined Combustion Catalyst and High Energy Density Fuel, Energy and Fuels, 23 (12): 6111-6120.

6. Mortensen M.W., Sorensen P.G., Bjorkdahl O., Jensen M.R., Gundersen H.J.G., Bjornholm T. 2006. Preparation and Characterization of Boron Carbide Nanoparticles for Use as a Novel Agent in T Cell-guided Boron Neutron Capture Therapy, Appl. Radiat. Isotopes, 64: 315-324.

7. Zhang X.W., Zou Y.J., Yan, H., Wang B., Chen G.H., Wong S.P. 2000. Electrical Properties and Annealing Effects on the Stress of RF-sputtered c-BN Films, Mater Lett., 45: 111-115.

8. Nowack B., Bucheli T.D. 2007. Occurence, Behavior and Effects of Nanoparticles in the Environment, Pollution, 150: 5-22.

9. Özkan Y., Altınok İ., İlhan H., Sökmen M. 2015. Determination of $\mathrm{TiO}_{2}$ and $\mathrm{AgTiO}_{2} \mathrm{Nanoparticles}$ in Artemia Salina: Toxicity, Morphological Changes, Uptake and Deputation, Bull. Environ. Contam. Toxicology, 96 (1): 36-42. 
10. Özkan Y., İrende İ., Akdeniz G., Kabakçı D., Sökmen M. 2015. Evaluation of the Comparative Acute Toxic Effects of $\mathrm{TiO}_{2}$ and $\mathrm{Ag}-\mathrm{TiO}_{2}$ and $\mathrm{ZnO}-\mathrm{TiO}_{2}$ Composite Nanoparticles on Honey Bee (Apis Mellifera), J. Int. Evironmental Application \& Science,10(1): 26-36.

11. Carpita N.C., Gibeaut D.M. 1993. Structural Models of Primary Cell Walls in Flowering Plants: Consistency of Molecular-structure with the Physical Properties of Walls During Growth, Plant Journal, 3: 1-30.

12. Navarro E., Baun A., Behra R., Hartmann N.B., Filser J., Miao A., et al. 2008. Environmental Behavior and Ecotoxicity of Engineered Nanoparticles to Algae, Plants and Fungi, Ecotoxicology, 17: 372-86.

13. Navarro E., Piccapietra F., Wagner B., Marconi F., Kaegi R., Odzak N., et al. 2008. Toxicity of Silver Nanoparticles to Chlamydomonas Reinhardtii, Environ. Sci. Technology, 42: 8959-8964.

14. Lin S., Reppert J., Hu Q., Hunson J.S., Reid M.L., Ratnikova T., et al. 2009. Uptake, Translocation and Transmission of Carbon Nanomaterials in Rice Plants, Small, 5 (10): 1128-1132.

15. Liu Q., Chen B., Wang Q., Shi X., Xiao Z., Lin J., et al. 2009. Carbon Nanotubes as Molecular Transporters for Walled Plant Cells, Nano Letter, 9: 1007-1010.

16. Vallyathan V., Shi X. 1997. The Role of Oxygen Free Radicals in Occupational and Environmental Lung Diseases, Environmental Health Perspectives, 105: 165-177.

17. Bonner J.C. 2007. Lung Fibrotic Responses to Particle Exposure, Toxicologic Pathology, 35 (1): 148-153.

18. Manke A., Wang L., Rojanasakul Y. 2013. Mechanisms of Nanoparticle-Induced Oxidative Stres and Toxicity, Biomed Research International, 2013: 1-15.

19. Gill S.S., Tuteja N. 2010. Reactive Oxygen Species and Antioxidant Machinery in Abiotic Stress Tolerance in Crop Plants, Plant Physiol. Biochem., 48 (12): 909-930.

20. Knaapen A.M., Borm P.J.A., Albrecht C., Schins R.P.F. 2004. Inhaled Particles and Lung Cancer, Part A: Mechanisms, International Journal of Cancer, 109 (6): 799-809.

21. Risom L., Møller P., Loft S. 2005. Oxidative Stress-induced DNA Damage by Particulate Air Pollution, Mutation Research, vol. 592 (1-2): 119-137.

22. Oberdörster G., Oberdörster E., Oberdörster J. 2005. Nanotoxicolgy, An Emerging Discipline Evolving from Studies of Ultrafine Particles, Health Perspective, 113: 823-839.

23. Daughton C.G. 2004. Non-Regulated Water Contaminants: Emerging Research, Environmental Impact Assessment Review, 24: 711-732.

24. Wolverton B.C., McDonald R.C. 1975. Water Hyacinths and Alligator Weeds for Removal of Silver, Cobalt, and Strontium from Polluted Waters, NASA Tech. Memo. No. TM-X-72727.

25. Wilde W.E., 1993. Benemann, J.R. Bioremoval of Heavy Metals by the Use of Microalgae, Biotechnology Advances, 11 (4): 781-812.

26. Maeda S., Skaguchi T. 1990. Accumulation and Detoxification of Toxic Metal Elements by Algae in: I. Akatsuka (Ed.), Introduction to Applied Phycology, Academic Publishing, Hague.

27. Dağlıŏlu Y., Altınok İ., İlhan H., Sokmen M. 2016. Determination of the Acute Toxic Effect of ZnO-TiO2 Nanoparticles in Brine Shrimp (Artemia Salina), Acta Biologica Turcica, 29 (1): 6-13.

28. Grace J.B. Wetzel R.G. 1978. The Production Biology of Eurasian Watermilfoil (Myriophyllum Spicatum L.): A review, J. Aquat. Plant Manage, 16: 1-11.

29. Smith C.S., Barko J.W. 1990. Ecology of Eurasian Watermilfoil, J. Aquat. Plant Manage, 28: 5564.

30. Altınayar G. 1988. Su Yabancı Otları, T.C. Bayındırlık ve İskan Bak. Dev. Su İşleri Genel Müd. İşletme ve Bakım Dairesi Başkanlığı, Ankara. 
31. Aiken S.G., Newroth P.R., Wile I. 1979. The Biology of Canadian Weeds.: 34. Myriophyllum Spicatum L., Canadian Journal of Plant Science, 59: 201-215.

32. Adams M.S., Titus J., McCracken M. 1974. Depth Distribution of Photosynthetic Activity in a Myriophyllum, Spicatum Community in Lake Wingra, Limnology and Oceanography, 19 (3): 377389.

33. Barko J.W., Smart M. 1986. Sediment-related Mechanisms of Growth Limitation in Submersed Macrophytes, Ecology, 67: 1328-1340.

34. Gross M.E., Meyer H., Schilling G. 1996. Release and Ecological Impact of Algicidal hydrolysable polyphenols in Myriophyllum Spicatum, First Publ.in : Phytochemistry, 41: 133-138.

35. Planas D., Sarhan F., Dube L., Godmaire H., Cadieux C. 1981. Ecological Significance of Phenolic Compounds of Myriophyllum Spicatum, Verh. Int. Verein. Limnol. 21, 1492.

36. Hothem S.D., Marley K.A. Larson R.A. 2003. Photochemistry in Hoagland's Nutrient Solution, Journal of Plant Nutrition, 26 (4): 845-854 .

37. Defontaine A., Lecocq M.F., Hallet J. 1991. A Rapid Miniprep Method for the Preparation of Yeast Mitochondrial DNA, Nucleic Acids Research, 19 (1): 185.

38. Heath R.L., Packer L. 1968. Photoperoxidation in Isolated Chloroplast: I. Kinetics and Stoichiometry of Fatty Acid Peroxidation, Arch. Biochem. Biophys, 125: 189-198.

39. Mukherjee S.P., Choudhuri M.A. 1983. Implications of Water Stress-induced Changes in the Levels of Endogenous Ascorbic Acid and Hydrogen Peroxide in Vigna Seedlings, Physiol. Plant, 58: 166-170.

40. Teranishi Y., Tanaka A., Osumi M., Fukui S. 1974. Catalas Activity of Hydrocarbon Utilizing Candida Yeast, Agr. Biol. Chemistry, 38: 1213-1216.

41. Beauchamp C., Fridovich I. 1971. Superoxide Dismutase: Improved Assays and an Assay Applicable to Acrylamide Gels, Analytical Biochemistry, 44 (1): 276-287.

42. Çolak A.D., Has B. 2016. NiFe2O4 Nanokompozitinin Olası Toksik Etkisine Karşı Olueropein'in Koruyucu Rolü, Erzincan University Journal of Science and Technology, 9 (2): 172-183. 